\title{
Vapaa sivistystyö ratsastaa jälleen
}

Seppo Niemelä ei ole

käyttänyt aikaansa sivistystyön ajattelijana turhaan. Hän on työstänyt vapaata sivistystyötä koskevien pohdintojensa tuoreimmat pääjuonteet 88sivuiseksi pokkariksi "Vapaa sivistystyö 2000-luvun kynnyksellä”. Kirja on haastava ja tekijänsä persoonankin peliin pistävä keskustelupuheenvuoro, johon toivoisi kohdistettavan kysymyksiä ja kommentteja. Samalla se on ehdotus jäsennykseksi vapaan sivistystyön tehtävää vuosituhannen vaihtuessa. Vielä tiiviimmin sama ehdotus on koottu Vapaan sivistystyön yhteisjärjestön julkaisemaan vihkoseen "Kutsu vapaan sivistystyön vision rakentamistyöhön"(1999).

\section{Nyt käsillä olevan}

kirjan optimistinen pääviesti on, että ammatillisen ja tutkintotavoitteisen koulutuksen kasvun myötä näivettyväksi sivujuonteeksi ennustetun vapaan sivistystyön aika ei olekaan mennyt, vaan oikeastaan vasta tulossa. Nimenomaan myöhäisteollisessa ja postmodernissa maailmassa tarvitaan ihmisen persoonallisen kasvun vahvistamista, yhteisöllisyyden tukemista ja kansalaisten tosiosallistumiseen perustuvan demokratian pohjan lujittamista. Kaikilla näillä alueilla vapaa sivistystyö voi tehdä merkittäviä tekoja.

Mikäli vapaa sivistystyö, ja/tai jotkut muutkin yhteiskunnan toimintakentät, ei ota näitä tehtäviä hoitaakseen, eivät Huxleyn Uljaan uuden maailman kaltaiset näyt välttä- mättä ole kovin kaukana toteutuvasta todellisuudesta. Jos ihmisen omaehtoinen ja itseisarvoinen " kasvu omaksi itsekseen" tavoitteena jää toiselle sijalle puhtaan taloudellisia arvoja edustavan joustava työntekijä - reipas kuluttaja -ulottuvuuden päästessä sen edelle on paljon menetetty. Elinikäisen oppimisen idea kun ei ole pelkässä oppiajan pituudessa vaan keskeisesti siinä, mitä opitaan tai minkä oppimiseen tarjoutuu mahdollisuuksia.

\section{Huolehtiessaan}

humanistisen, ihmisen kokonaispersoonallisuuden kehittymiseen tähtäävän ideaalin toteutumisesta Niemelä pitää tärkeänä useampaankin otteeseen muistuttaa siitä, että tietoyhteiskunnankaan ihminen ei ole vain "pää", vaan myös "kädet". Sivistystyö ei saisi kohdistua vain tietämisen lisäämiseen vaan entistä painokkaammin myös taitamisen ja käsillä tekemisen perustan vahvistamiseen.

\section{Sivistystyön alueina} nämä "handen och anden" ikään kuin vaihtavat paikkaa verrattuna kansansivistystyön alkuaikoihin. Tällöinhän pyrittiin tarjoamaan "hengen viljelyä" ruumiillisen työn raatajajoukoille. Nyt kun yhä useampi on tavalla tai toisella tietotyössä automaation vähentäessä fyysisen työn määrää, on jo puutetta paikoista, joissa voi opetella tekemään jotakin konkreettista omin käsin, luoda esimerkiksi kauneuden ja käytännöllisyyden käsin kosketeltavia yhdistel- miä, ovat ne sitten tekstiilitöitä, taloja tai vaikka harjanvarsia.

\section{Yhteisöllisyyden Niemelä näkee vapaan sivistystyön erityisenä tehtävänä, joka sille sopii jo vapaan sivistystyön organisaatioiden yhteisöllisen perinteen (esimerkiksi kansan- liikepohjaiset sivistysjärjestöt ja kansanopistot) ja ihmisten väliseen vuorovaikutukseen ja dialogisuuteen perustuvien pedagogisten lähestymistapo- jen (esimerkiksi opintokerho, tutkiva opiskelu, ongelman- ratkaisumenetelmät, opinto- jen järjestäminen yhteisölli- siksi projekteiksi) vuoksi.}

\section{Uusien yhteisöllisten} rakenteiden luominen on tärkeää aikana, jolloin kansantaloudet ovat jäsentyneet monimutkaisin välityksin toisistaan riippuvaiseksi globaaliksi verkostoksi. Samanaikaisesti "yhteisten asioiden hoito" muokkautuu talouden, tekniikan ja hallinnan ammattilaisten ja asiantuntijoiden työalueeksi, joka on vaarassa erkaantua ihmisten arkipäivästä ja elämismaailmasta.
Vapaa sivistystyö voi olla mukana kutomassa kansalais- yhteiskunnan verkkoja ja tu- kemassa lokaalista ja globaalis- ta ihmisten välistä yhteistoi- mintaa. Se voi tarjota tähti- torneja, laboratorioita ja kes- kustelufoorumeja, joissa ih- miset ihan itse voivat tutkia maailmaa, muodostaa näke- myksiä ja ryhtyä toteuttamaan itselleen tärkeitä asioita yh- dessä toisten kanssa. 


\section{K I R J A - A R V I O I T A}

Samalla vapaa sivistystyö voi luoda vuoropuhelua päätöksentekijöiden ja kansalaisten välille, paikkoja joissa nämä voivat aidosti kohdata toisensa. Tämä on ehkä myös tapa lisätä monen yhteiskuntatutkijan peräänkuuluttamaa politiikkaa politiikkaan, tarkoittaen sekä yhteiskunnallisten ongelmamääritysten että tarjolla olevien ratkaisuvaihtoehtojen arvoperustaisen kirjon kasvattamista. Se on jo kolmatta tehtäväaluetta, demokratian perustan vahvistamista. Siihen voi ajatella kuuluvan myös Niemelän kirjassaan vapaan sivistystyön erityiseksi tehtäväksi globaalissa markkinataloudessa hahmottaman yhteiskunnallisen, taloudellisen ja kulttuurisen syrjäytymisen vastustamisen.

\section{Hyvä kysymys, johon}

Niemelä ei aivan eksplisiittisesti (ainakaan vielä) vastaa, on, keiden asia vapaa sivistystyö on ja ketkä sitä "saavat" tehdä. Legalistinen ajattelu johtaa helposti vastaamaan, että tontit on jaettu Vapaan sivistystyön lain piiriin kuuluville oppilaitoksille ja sivistysorganisaatioille. Tällöin olisi vain luotettava siihen, että olemassa olevilla organisaatioilla on viisautta ja välineitä erottaa oikeat ajan merkit niiden oman menneisyyden välkkeestä ja ympärillä vellovasta markkinatalouden taustakohinasta. Toisaalta niillä toki olisi oltava myös potentiaalia notkean ameebamaisesti reagoida alituiseen muuttuvan toimintaympäristön asettamiin, osin vain hämärästi näkyviin sivistyshaasteisiin.

Yksi vastausmahdollisuus on, että iso osa aikamme vapaasta sivistystyöstä on vapautunut myös vapaan sivistystyön organisaatioista ja tapahtuu esimerkiksi työttömien yhdistyksissä, rocklyriikassa ja musiikissa, kyläprojekteissa, tietoverkkokeskusteluissa ja monenlaisten asioiden ympärille syntyvissä spontaaneissa ryhmissä jotka hajoavat sitten kun tehtävä on tullut tehdyksi tai muut houkutukset vetävät osallistujat puoleensa.

\section{Ehkäpä joko-tain sijasta} sekä-että olisi kuitenkin paras vastaus? Yhdistelmä, jossa olemassa oleva oppilaitoskenttä henkilöstöineen ja ammattitaitoineen voisi verkostua uusien ja yllättävien porukoiden, tekemisen tapojen ja yhteisöllisen toiminnan ulottuvuuksien kanssa, tuntuisi houkuttavalta. Tämä seuraisi myös vapaan sivistystyön logiikkaa, jossa moniarvoisuus, omaehtoisuus ja vapaus eivät ole vain sivistystyön ulkopuoliselle maailmalle asetettavia vaatimuksia vaan myös sen itseensä kohdistamia periaatteellisia velvoitteita.

\section{Niemelän kirjan paikoit-} tainen luonnosmaisuus ei ole teokselle vahingoksi. Se vain kertoo siitä, että ajatteluprosessi on nyt tässä vaiheessa ja jatkuu edelleen.

Pertti Rantanen 